Draskhanakerttsi (p. 68), without any reference to the literature. The lack of the "Byzantine perspective" is also visible in parts devoted to Persian and Arab victories over the Byzantines - the author repeats outdated hypothesis concerning the alleged impact of the "dissatisfaction" of Syrian and Egyptian Monophysites or Jews on the defeat of Byzantine Empire in the two Middle Eastern provinces (p. 74-75, 88). It is much more surprising if we consider that one of the main researchers of these issues, who created new hypotheses rejecting these interpretations, is a Russian scholar dealing with Byzantium, Mikhail V. Krivov ${ }^{55}$.

${ }^{5}$ М.В. Кривов, Отнотение сирийских моно-
Despite the remarks made above, the work of Arsen Shahinyan should be considered as one of the most important recent studies of the history of medieval Armenia. It will be particularly helpful for researchers working on relations of the Byzantine Empire with Sassanid Persia and the Arab Caliphate, mainly due to its original attitude towards the history of the Caucasian countries of the $6^{\text {th }}$ to $9^{\text {th }}$ centuries based on Armenian, Persian and Arab sources.

Błażej Cecota (Lódź / Piotrków Trybunalski)

фиситов к арабскому завоеванию, ВВ 55, 1994, p. 95-103.

\title{
ТАТянА СлАвОВА, Славянският превод на Посланието на патриарх Фотий до княз Борис-Михаил [Slavic translation of the Letter of Patriarch Photios to Prince Boris-Michael], Университетско издателство „Св. Климент Охридски“, София 2013, pp. 344 [= История и книжнина].
}

The monograph by Tatiana Slavova, released by the University of Sofia Publishing House as the thirteenth volume of the series "История и книжнина", provides an extensive multi-faceted study of the Slavic version of the letter that the Constantinople Patriarch Photios sent to the then ruler of Bulgaria, Boris I (Michael), in the ninth century (probably between 864 and 866) regarding the latter's adoption of the Christian religion. This document, preserved in a number of manuscript copies, has been translated over the centuries into a number modern languages (including Bulgarian, Greek, French, English, and Russian), it has had many editions, and has been a subject of numerous published studies (the unflagging interest it continues to provoke among scholars is evidenced by the fact that many publications on the topic have been written and released in the last thirty years). This publication includes a critical edition of the Slavic version of both parts ${ }^{1}$ of the letter,

\footnotetext{
${ }^{1}$ The letter by Photios consists of two parts, the first devoted to the Christian dogmas, while the second discusses the responsibilities of a Christian ruler to his subjects (cf. Introduction to the edition, p. 5).
}

developed based on examination of 8 complete Ruthenian copies of the text dated from the sixteenth until eighteenth centuries, as well as four abridged ones and one old print dated 1644 . The edition itself has been set in an appropriate historical context and enriched, in addition to the textological investigations, with the study of the language of the text, which constitutes the only source that makes dating the translation possible $^{2}$.

The publication consists of eight chapters, which is complemented by a list of abbreviations, a list of references, and an abstract in the English language.

In the first chapter, entitled Ръкописната традиция [Manuscript Tradition] (p. 9-28), the author focuses first on the existing Slavic editions of the letter and manuscripts on which they were based, presenting their archeographic data in detail (p. 9-20), followed by the codicological characteristics of the manuscript РГБ, Ф. 178, № 3112 (the oldest complete copy of the text of Photios, made in the first quarter of the sixteenth century), which served as the basis of

\footnotetext{
${ }^{2}$ The author mentions it in the Introduction, p. 8.
} 
its publication (it is important to note that the copy had not been previously published or even examined) and the most important orthographical features compared with the other seven complete Ruthenian copies of the text of the letter (ГИМ, Син № 235/384; РГБ, Ф. 113, № 522; РГБ, Ф. 113, № 488; РГБ, Ф. 113, № 489; РГБ, Ф. 113, № 506; РГБ, Ф. 310, № 588; ГИМ Син № 996) (p. 20-28).

Chapter two, Славянският превод на Посланието на патриарх Фотий и неговият грғики оригинал [Slavic translation of the Letter of Patriarch Photios and its Greek original] (p. 29-42), begins with the presentation of the Greek original - the entire text in manuscripts dated from the ninth until sixteenth century ${ }^{3}$, various portions of the text included in different Greek (including books dated from the twelfth, fourteenth and fifteenth centuries) and a 1852 copy made by a Bulgarian monk Dimitr Dipčev, known as Damaskin Veleški or Damaskin Rilec, and then - a list of text missing in the Slavic translation in relation to the Greek original (a total of 5 lines) and Slavic supplements of the Greek text (also a small number). On the basis of a comparative textological study, the author concludes that the archetype of the Slavic text does not fully correspond to any of the Greek copies included in the critical edition of the original by Laourdas and Westerink ${ }^{4}$, but its closest equivalent is the tenth century copy, which served as the basis fora critical edition released in 1983 (Ambrosianus B4sup = Gr. 81). In describing the technique of translation, the researcher notes that the translation faithfully reproduces the original, which was possible to achieve through the use of calques of the Greek language composites. With truly painstaking accuracy, the author counts specific words, compares their structure, and finally, after the presentation of the material (or rather in addition to it), shows the reader a statistical summary of the translation of the various types of forms.

\footnotetext{
${ }^{3}$ They were the basis for the critical edition: Photii Patriarchae Constantinopolitani Epistulae et Amphilochia, ed. B. Laurdas, L.G. Westerink, vol. I, Lipsae 1983.

${ }^{4}$ Cf. p. 31 of the monograph.
}

Examples of source texts presented in the second chapter are only an introduction to the principal presentation of linguistic material in the third chapter - Езикът на славянския превод на Посланието на патриарх Фотий [Slavic language translation of the Letter of Patriarch Photios] (p. 43-121). It is the most comprehensive part of the monograph, whose preparation cost the author a lot of effort and patience, not only while collecting the material, but also (and perhaps: first of all) during its editorial development. At the same time it should be emphasized that this chapter is very important for the whole study of the Slavic text of Photios's letter, because only examination of its language (in the absence of other direct evidence thereof) makes it possible to collect information about when and where the translation was made. Slavova analyzes the language of the text comparing it with the Greek original on several levels: morphological, syntactic, lexical and related to word formation, and some of the results she presents in a table in the form of statistical data. As a result of in-depth study of the language of the letter, the author manages to find links between the Slavic translation of the work and the Bulgarian literary language of the fourteenth century, and representatives of the Tarnovo School of writing.

The author devotes the next chapter, Текстология на славянския превод на Посланието на патриарх Фотий до княз Борис-Mихаил [Textology of the Slavic translation of the Letter of Patriarch Photios to Prince Boris-Michael] (p. 122-145), to textological characteristics of individual copies or groups (deficiencies, supplements, errors, differences in order, morphological and formative differences), the comparison of which statement leads to the differentiation of two separate texts archetypes, within which subtypes can be distinguished based on certain (non)regularities. First, the description includes full copies, then abridged ones, the old print, and finally - for comparison - the Church Slavic copy by Damaskin Veleški. A summary of text extracts also allows the author to determine the source which Damaskin was using when working on his own Slavic translation.

In the fifth chapter, entitled Датиране на превода. Исторически контекст за появата 
my [Dating the translation. The historical context of its creation](p. 146-158), Slavova presents current theories concerning date when the Slavic version of the text was created, and - on the basis of her own analysis of the linguistic characteristics, she presents convincing arguments that date the text no earlier than the late fourteenth century ${ }^{5}$.

Chapter six (Принциии на издаване на текста [Principles of text publication], p. 159160) presents the rules of text edition adopted by the author. On the subsequent several dozen pages, one will find an edition of the letter itself (chapter seventh, Издание на текста [Publication of the text], p. 161-245), which became the basis for the above-cited manuscript РГБ, Ф. 178, № 3112, supplemented by lections of the other 7 full copies and the old print. Irregularities noted in the body text and/or lections are commented by quoting the Greek original based on the edition by Laourdas and Westerink.

In chapter eight (Речник-индекс на словоформите [Glossary-Index of words],p.246325 ), the author provides an alphabetical list of 2,075 lexical units (excluding pronouns, numerals, conjunctions, prepositions, and particles) attested in the Slavic translation of the letter by Photios. Each dictionary entry from the source contains a semantic definition, all word forms attested in the primary copy, along with their

${ }^{5}$ According to certain researchers the Slavic translation of the letter by Photios dated back to the tenth century, or even the late ninth century a cf. p. 146 of the monograph. location (card and verse), and their Greek counterparts (according to the critical edition by Laourdas and Westerink).

The latest publication by Tatiana Slavova is an excellent addition to her research on textology and history of language she has been conducting for many years (with particular emphasis on lexicology) $)^{6}$ and certainly can be a valuable and reliable source of information for researchers in many fields. Not to be underestimated is also the author's contribution in the dissemination of knowledge about the ancient history of the southern Slavs and their relationship with the Byzantine culture. The critical edition of the text, which usually poses many problems of varying nature at the development stage (such as selecting texts, comparison thereof, and the necessity to resolve the problems of spelling), is extremely transparent conceptually (and thus readable), and probably will often serve as a valuable material for further research.

Translated by Katarzyna Gucio

Agata Kawecka (Łódź)

${ }^{6}$ Cf. е.g.: Т. Славова, Владетел и администрачия през ранното Средновековие в България. Филологически аспекти, София 2010; Тълковната палея в контекста на старобългарската книжнина, София 2002; Речник на словоформите в Архангелското евангелие от 1092 г., София 1994; Преславска редакиия на Кирило-Методиевия старобългарски евангелски превод, КМс 6, 1989, р. 15-129; Помагало по българска историческа лексикология, София 1986 et al.

\section{IzABELA Lis-Wielgosz, O trwałości znaczeń. Siedemnastowieczna literatura serbska $w$ stużbie tradycji [On Permanence of Meaning. The Serbian Literature of the Seventeenth Century in Service with Tradition], Wydawnictwo Naukowe UAM, Poznań 2013, pp. 336.}

From the research point of view, the description of the seventeenth century cultural space phenomena in the Balkan Peninsula is quite complicated and multifaceted. This is due to primarily the dynamics of the events of that era, as well as rich and yet extremely diverse source material, which has survived into modern times. For this reason, some researchers consider this age an important time of change, which often results in the overestimation of the events of this period. On the other hand, some other scholars marginalize this century and do not see it as anything groundbreaking. There is no doubt, however, that many publications in the academic literature, on both philological, and historical aspects of the seventeenth century Serbian culture were 